been commemorated. The memorial in Dublin may be unique as one commemorating a particular discovery in mathematics, and must surely be unique as one inaugurated by the head of a Government who personally appreciates the significance of an achievement of this kind.

\section{British Museum (Natural History): The Hedges Collection of British Moths}

Among the more important acquisitions recently reported to the Trustees of the British Museum (Natural History) was the Alfred Vander Hedges collection of British moths presented by Mrs. Celia Hedges, in accordance with the wish of her late husband. The collection is a very extensive one, comprising about 20,000 specimens, and consists almost exclusively of specimens reared in captivity by Mr. Hedges. Some of the specimens had been reared in experiments in connexion with genetical studies in co-operation with the late Dr. E. A. Cockayne, whose collections are already the property of the Museum. Others are the result of his intensive collecting in the Isle of Man, as a consequence of which many species previously unknown in that Island were discovered to be present. The whole collection is in the most perfect condition.

\section{The National Trust}

THE sixty-third annual report of the National Trust presented to the annual meeting on November 7 records a further increase of membership to 70,687 during the first five months of the year, but the figure is still short of the 100,000 the Council hopes to reach by January 1960, and only a membership consonant with its responsibilities can enable the Trust to exert its full influence for the preservation of the best of the countryside and Britain's finest buildings. The report refers to the need to dispel widespread misapprehension arising from the title 'National Trust', which tends to obscure the Trust's dependence on voluntary support. Emphasis is also placed on the changes in method which the Trust has had to adopt now that it is increasingly concerned with the impact of the public on the countryside. Its duty has often become one of control to preserve the countryside from damage by litter hooliganism or even the sheer wear of numbers on a limited area. The Trust has had to face unpopularity in some quarters in confining the public to footpaths on agricultural land, in strictly limiting caravans, tents and car parks to appropriate sites, and generally in regulating access to its open spaces. Certain changes in the administration of the Trust are being made in accordance with the recommendations of a special committee appointed to consider the subject, and the first regional secretary has been appointed. The Trust's nature reserves continue to prosper and are becoming increasingly important. The new mere at Wicken Fen has already attracted a large variety of ducks and waders; the eider is again breeding in the Farne Islands in everincreasing numbers and 600 pairs of Sandwich terns are known to have nested at Blakeney, while figures for redshank and little tern were also well above the average.

\section{Forest Products Statistics}

WITH the completion of the decade of publication of the Yearbook of Forest Products Statistics, the Forestry Division of the Food and Agriculture Organization of the United Nations has decided that in view of the considerable progress that had been achieved in making the compilation more complete, more uniform and more accurate, it would be of value to revise the earlier issues, bringing the data as nearly in line as possible with the latest, and to publish a ten-year summary. The particular value of such a summary (World Forest Products Statistics : a Ten-Year Summary, 1946-1955. Pp. viii +197. Rome : Food and Agriculture Organization; London : H.M. Stationery Office, 1958. 15s.; 3 dollars) lies in its use for the study of trends, which have become so important with the rapid developments in production and use of timber in most parts of the world.

This development is continually in progress and is exemplified in the Yearbook for 1957 (Pp. vi +169 . Rome : Food and Agriculture Organization; London : H.M. Stationery Office, 1957. 12s. 6d. ; 2 dollars) by the provision of separate statistics for particle board (defined as a board "constituted from fragments of wood and/or other vegetable materials which have been comminuted and then consolidated by pressure, heat, etc., with or without binders and supplementary materials"). World production of these materials rose from less than 500,000 metric tons in 1955 to 705,000 metric tons in 1956, more than half being in the United States and Germany, and there is every indication that there will be continued expansion in the future; there are factories in the United Kingdom, but the total output is still small. Another change in this issue is the inclusion of estimates for the relatively fow countries from which returns have not been received; without these, regional totals can be very misleading.

\section{Progress in Geology}

The present century has, perhaps, been more notable for advances in techniques and in the accumulation of detailed knowledge than in the formulation of radically fresh ideas in geology, and it is of interest to inquire what general trend is discernible in the interpretation of the Earth's history as a result of these advances. Prof. L. Hawkes, in his anniversary address to the Geological Society of London (Quart. J. Geol. Soc., 133, 309; 1958), considers that vindication of the Lyellian doctrine of uniformitarianism has been the central theme of progress in geology in the past fifty years. During this period determination of the age of minerals by radioactive decay methods has underlined the immensity of the geological time-scale. At the same time, precise geodetic measurements have disclosed crustal movements in various parts of the world to-day proceeding at rates which, bearing this time-scale in mind, are adequate to account for the huge deformations of the past, thus extending the principle of uniformitarianism to the field of tectonics. Not only must earlier ideas on the catastrophic nature of mountain-building processes be discarded, but the presumed world-wide synchronism of mountain-building periods may also be seriously challenged as isotopic methods of dating and correlating sediments are improved. There may be no 'pulse of the Earth'. Normal sedimentary rocks were being formed at least 3,000 million years ago, and there is now direct fossil evidence for the existence of simple forms of life more than 2,000 million years ago. Conditions on the Earth's surface seem to have been much the same as they are to-day over a much longer span of time and in more ways than would genorally have been believed possible fifty years ago. 